\title{
Upaya pedagang kaki lima dalam mengatasi terpaan berita penyebaran Covid-19 di televisi
}

\author{
Intan Fadhilla ${ }^{1^{*}}$, Ferdinandus Ngare $^{2}$ \\ 1,2 Universitas Adhiradjasa Reswara Sanjaya
}

\begin{abstract}
In a covid-19 pandemic situation like this, television media as information presenters, make social contributions by reporting to discussing social realities regarding the latest developments regarding the spread of the covid-19virus that is currently happening. In this case, news on television is the daily intake of the community, including the street vendors. Many media continued to launch and report the news to street vendors, who could not follow the government's directives to stay at home, because of the demands of work and the daily economy. However, the effect of news exposure is felt by street vendors and has its impact on them, so efforts are needed to overcome the exposure to the covid-19 news. This study aims to determine how the community's efforts to deal with exposure to covid-19 news on television. The research method used is a descriptive qualitative research method, using the theory of individual differences. The results of the research obtained from this research are street vendors in Cikedokan village, who are often exposed to news about covid-19 on television every day with a high frequency of broadcasts (often), so an effort to overcome exposure to the news is to limit yourself to watching. the latest news about covid-19 that is broadcast, besides that, street vendors are more selective in choosing good news for consumption so that it does not affect their attitudes and work in their day to day and do not forget to also obey government directions and ask more people. understand a situation like this pandemic.
\end{abstract}

Keyword: Covid-19, effort, mass communication, news exposure, television

\begin{abstract}
Abstrak: Dalam situasi pandemi covid-19 seperti ini, media televisi sebagai penyaji informasi, memberikan kontribusi sosial dengan melaporkan hingga membahas realita sosial mengenai perkembangan terkini penyebaran virus covid-19 yang sedang terjadi. Dalam hal ini, berita dalam televisi menjadi asupan sehari hari masyarakat, tak terkecuali pedagang kaki lima. Sejumlah media terus melansir dan memberitakan berita tersebut pada pedagang kaki lima, yang tidak bisa mengikuti arahan pemerintah untuk diam dirumah aja, karena tuntutan pekerjaan dan perekonomian sehari hari. Namun, efek terpaan berita dirasakan oleh pedagang kaki lima, dan memiliki dampak tersendiri bagi mereka, untuk itu diperlukan upaya untuk mengatasi terpaan berita covid-19 tersebut. Penelitian ini bertujuan untuk mengetahui bagaimana
\end{abstract}

*Corresponding Author: Intan Fadhilla | fadhillaintan992@gmail.com | Universitas Adhiradjasa Reswara Sanjaya, Jl. Sekolah Internasional No 1 - 2, Antapani, Bandung, Indonesia. 
upaya masyarakat dalam mengatasi terpaan berita covid-19dalam televisi. Metode penelitian yang digunakan adalah metode penelitian deskriptif kualitatif, dengan menggunakan teori perbedaan individu. Hasil penelitian yang diperoleh dari penelitian ini adalah pedagang kaki lima yang ada di kampung Cikedokan, sering diterpa pemberitaan mengenai covid-19 dalam televisi setiap hari dengan frekuensi tayangan tinggi (sering), sehingga upaya untuk mengatasi terpaan berita tersebut, adalah dengan membatasi diri untuk menonton berita terbaru mengenai covid-19 yang ditayangkan, selain itu, pedagang kaki lima sudah lebih selektif dalam memilih pemberitaan yang baik untuk dikonsumsi supaya tidak mempengaruhi sikap dan pekerjaan mereka dalam sehari hari, dan tidak lupa juga tetap mematuhi arahan pemerintah serta bertanya kepada orang yang lebih paham akan situasi seperti pandemi ini.

Kata Kunci: Covid-19, komunikasi massa, televisi, terpaan berita, upaya.

\section{Pendahuluan}

Saat ini dunia sedang dilanda pandemi kasus virus Covid-19 Virus yang berasal dari kota Wuhan, China, awalnya ditemukan pada bulan Desember 2019. Karena penye-barannya yang begitu cepat dan tidak kasat mata ke berbagai Negara, Organisasi Kesehatan Dunia (WHO) menyebutkan bahwa dampak dari penyebaran virus ini sangat banyak, bahkan WHO menetapkan status covid-19 sebagai pandemi internasional. Di Indonesia sendiri, kasus pertama muncul setelah presiden mengumumkan dua warga Depok terkena virus covid-19 setelah melakukan kontak dengan warga asing, pada bulan Maret lalu. Mulai saat ini, pemerintah di Indonesia berupaya agar virus ini tidak menyebar luas di Indonesia. Namun akibat dari ketidak pedulian masyarakat, pada akhir bulan Maret 2020, terjadi lonjakan tertinggi sebanyak 100 kasus per hari dari penambahan rata-rata sebelumnya (Lokadata.id, 2020a).

Hal ini menjadi hangat untuk diperbincangkan, seolah-olah perhatian publik hanya tertuju pada kasus virus Covid-19 tidak dipungkiri dalam hal penggunaan media.

Pandemi covid-19 telah menyebabkan perubahan perilaku masyarakat terhadap media, terutama media televisi, seperti karena penyebaran virus ini semakin luas maka semakin banyak pemberitaan yang ditayangkan dalam berita televisi, hal ini membuat masyarakat mulai memantau setiap perkembangan kasus setiap harinya. Media menjadi sumber informasi, dan alat kontrol dalam masyarakat. Informasi mengenai hal kecil, hal yang belum diketahui semua orang bahkan informasi yang tidak dibutuhkan sama sekali oleh masyarakat mengenai pandemi ini akan terus ditayangkan karena memang pandemi ini merupakan wabah serius yang sedang terjadi di lingkungan kita, sehingga media menjadi sangat dibutuhkan masyarakat.

Sementara pemerintah juga akan memberitahu tindakan dan upaya serta peristiwa - peristiwa yang terjadi dalam kasus ini melalui pemberitaan di media televisi. Semakin berkembangnya kasus ini, pemerintah semakin banyak 
mengeluarkan upaya untuk memutuskan rantai penyebaran virus, salah satunya dengan melakukan pembatasan sosial dan diam di rumah aja. Dengan tindakan pemerintah tersebut membuat masyarakat melakukan karantina mandiri di rumahnya masing masing dan tidak dipungkiri peningkatan konsumsi terhadap media juga meningkat.

Berdasarkan hasil pantauan Nielsen Television Audience Measurement (TAM) di 11 kota menunjukkan rata-rata kepemirsaan TV mulai meningkat dari 12\% di tanggal 11 Maret menjadi 13,8\% di tanggal 18 Maret yang setara dengan penambahan sekitar 1 juta pemirsa TV. Untuk durasi menonton juga mengalami peningkatan dari rata-rata 4 jam 48 menit di rating $11.2 \%$ menjadi 5 jam 29 menit di rating $13.7 \%$, pada tanggal 11 Maret sampai dengan 18 Maret. Kenaikan kepemirsaan mengenai maraknya pemberitaan terkait covid-19 di stasiun televisi pada 1-18 Maret berkontribusi pada program berita. Kecenderungan masyarakat dalam menonton televisi pada program berita naik secara signifikan yaitu $+25 \%$, terutama pada penonton kalangan atas (Nielsen.com, 2020).

Gambar 1. Grafik peningkatan konsumsi media televisi (Nielsen Company)

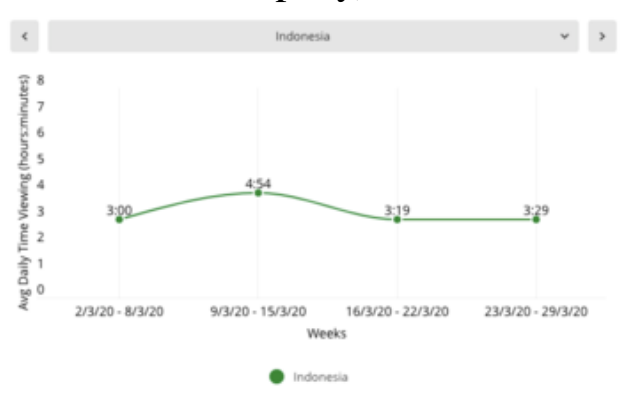

Grafik hasil riset Nielsen Media menyatakan, rata-rata waktu menonton TV masyarakat Indonesia di tanggal 2329 Maret ada di angka 3 jam 29 menit. Waktu rata-rata ini naik dari posisi pekan sebelumnya sebesar 3 jam 19 menit (Lokadata.id, 2020b).

Semakin kasus ini menyebar, semakin penting juga peran televisi, karena dengan banyak kasus maka media televisi akan sering menyampaikan informasi pada masyarakat, dan masyarakat membutuhkan informasi tersebut. Namun, terkadang hal itu banyak dimanfaatkan media dengan ikut memberitakan isu untuk kepentingan value dan keuntungan medianya itu sendiri. Seperti halnya berita mengenai peningkatan jumlah pasien yang meninggal, adanya orang tanpa gejala tetapi positif terkena virus, keterbatasan bahan makanan (sembako), pemutusan kontrak kerja, maraknya kasus kriminal, dan peredaran video mengenai orang yang tiba -tiba tergeletak di jalanan. Selain itu isu-isu hoaks yang di temukan oleh Kominfo juga semakin meningkat terutama di media sosial. Pakar komunikasi dari Universitas Atmajaya Yogyakarta, Lukas Ispandriarno, menilai bahwa ada media yang ingin memberikan informasi yang terverifikasi tetapi ada juga media yang tampak memanfaatkan isu virus corona untuk mendongkrak khalayak (Voaindonesia, 2020).

Imbas dari pemberitaan yang disampaikan dalam televisi, tidak sedikit menyebabkan warga menjadi lebih mudah terpengaruh dan membuat mereka menjadi cemas. Pasalnya, di setiap program berita, selalu ada 
pemberitaan mengenai perkembangan kasus Covid-19 jadi secara tidak langsung berita tersebut sering menerpa masyarakat setiap harinya. Tayangan berita mengenai covid-19 memberikan dampak yang besar bagi pemirsanya. Seringnya menonton tayangan berita covid-19 di televisi membuat orang beranggapan bahwa pandemi ini menjadi hal serius yang harus kita hadapi saat ini. Tayangan mengenai korban dan dampak pandemi yang dilihat pemirsa di televisi dapat menimbulkan kekhawatiran tersendiri. Pemberitaan ini bisa dirasakan oleh seluruh lapisan masyarakat, terutama masyarakat menengah ke bawah seperti para pedagang kaki lima yang kesehariannya bertemu banyak orang di lingkungan sekitarnya bahkan di pasar. Dengan adanya pandemi ini dan upaya pemerintah yang menyarankan untuk diam di rumah aja, tidak dipungkiri membuat para pedagang kaki lima ini sulit untuk melakukan pekerjaan seperti biasanya. Bahkan seringnya berita yang disampaikan dalam televisi mempunyai pengaruh besar terhadap pedagang kaki lima, karena disamping pemberitaan mengenai bahaya penyebaran virus ini seperti yang ditayangkan dalam televisi, mereka harus tetap berjualan untuk memenuhi kebutuhan perekonomian keluarganya. Tingkah media inilah yang menjadi hal menakutkan serta membuat banyak orang merasa cemas untuk menjalani kehidupannya.

Hal tersebut juga dirasakan oleh masyarakat kampung Cikedokan, Garut, dimana mata pencaharian mereka adalah sebagai pedagang kaki lima. Walaupun, pada awalnya kota Garut tidak begitu parah dalam jumlah kasus, namun dengan banyaknya perantau yang pulang kampung dari berbagai daerah, itu membuat para masyarakat di kota Garut serta pedagang kaki lima disini merasa lebih khawatir. Sesuai dengan informasi yang disampaikan berita dalam televisi, lonjakan perkembangan kasus yang terjadi, seperti penambahan kasus, test rapid, bantuan sosial dan bahkan ada pula yang mengabarkan terkait menghilangnya salah satu pasien ODP di rumah sakit Garut. Hal ini membuat pedagang kaki lima merasa cemas, karena mereka bertemu banyak orang yang menjadi pembelinya di lingkungan tersebut dan tidak tahu status kesehatannya, walaupun demikian mereka tetap saja berjualan ditengah bayaknya resiko yang akan diterima, untuk memenuhi kebutuhan perekonomian sehari-harinya.

Adanya keadaan ini, televisi memberikan efek positif dan negatif. Jadi apapun yang disampaikan oleh media akan menimbulkan efek secara langsung pada pedagang kaki lima karena mereka akan menerima informasi yang mereka butuhkan begitu saja di tengah kasus yang sedang terjadi. Tidak mengherankan seringnya berita mengenai covid-19 yang ditayangan oleh berita di televisi sudah dianggap biasa oleh masyarakat. Mereka tidak pernah mengetahui apakah tayangan itu berpengaruh atau tidak. Bagi sebagian masyarakat, berita di televisi hanyalah sebuah berita dan tidak membahayakan. Oleh karena itu, pandemi dan terpaan berita media ini membuat pedagang kaki lima merasa tidak aman dan secara tidak langsung merasa terganggu dalam 
menjalani pekerjaan sehari - harinya, maka dari itu, hal ini yang menjadi dasar peneliti untuk melakukan penelitian kualitatif dengan menggunakan metode deskriptif, sehingga peneliti bisa mengetahui dan menjelaskan bagaimana upaya Pedagang Kaki Lima dalam Mengatasi Terpaan Berita Penyebaran covid-19di Televisi.

\section{Pedagang kaki lima}

Menurut Peraturan Daerah No. 3 Tahun 2014 Tentang Penataan dan Pemberdayaan Pedagang Kaki Lima yang dimaksud dengan kaki lima yang selanjutnya disebut PKL adalah pelaku usaha yang melakukan usaha perdagangan dengan menggunakan sarana usaha bergerak maupun tidak bergerak menggunakan prasarana kota, fasilitas sosial, fasilitas umum, lahan, dan bangunan milik pemerintah dan atau swasta yang bersifat sementara dan tidak menetap (Yadewani, Syafrani, \& Ikhsan, 2020).

Media televisi dan dampak terpaan berita covid-19

Menurut undang undang Pers No 40/1999, media massa berfungsi untuk menginformasikan, mendidik, serta sebagai alat kontrol dan menghibur (Nadie, 2018). Televisi merupakan salah satu medium bagi para pemasang iklan di Indonesia. Media televisi merupakan industri yang padat modal, padat teknologi dan padat sumber daya manusia. Dari semua media komunikasi yang ada, televisi-lah yang paling berpengaruh pada kehidupan manusia (Nuruddin, 2007).
Sebagai alat untuk menyebarkan informasi dan sebagai alat kontrol sosial media mempunyai fungsinya (Effendy, 2006). Idealisme yang melekat kepada media dijabarkan dalam pelaksanaan fungsinya, selain menyiarkan informasi juga mendidik, menghibur dan mempengaruhi. Dapat disimpulkan bahwa media massa merupakan pesanpesan dari sumber kepada khalayak (menerima) komunikasi mekanis seperti televisi, radio, surat kabar, majalah, tabloid, buku, film, internet, dan lain-lain (Alamsyah, Amaliasari, \& Satriani, 2018).

Sedangkan, dampak sosial media massa televisi membentuk opini publik untuk membawanya pada perubahan yang signifikan (Abraham, 2017). Disini secara instan media massa dapat membentuk kristalisasi opini publik untuk melakukan tindakan tertentu. Kadang-kadang kekuatan media massa hanya sampai ranah sikap (Agee, 2001). Media massa, terutama televisi, yang menjadi agen sosialisasi (penyebaran nilai-nilai) memainkan peranan penting dalam transmisi sikap, persepsi, dan kepercayaan (Ardianto dan Erdinaya, 2005).

\section{Terpaan media}

Terpaan Media diartikan sebagai suatu kondisi dimana seseorang diterpa oleh isi media atau bagaimana isi media menerpa audience (Gussman \& Triwulandari, 2019). Kondisi tersebut seperti kegiatan mendengar, melihat, membaca atau mengakses pesan-pesan dari media. Maka, terpaan media massa adalah intensitas penonton atau khalayak dalam menerima pesan dari media 
massa, baik dalam kegiatan menonton televisi, mendengarkan radio, membaca koran hingga informasi dari internet (Gussman \& Triwulandari, 2019). Khalayak aktif memilih dan menggunakan media mana yang mampu memenuhi kebutuhan akan informasi serta dengan terpaan media dapat menimbulkan efek pada khalayak yang melihat, mendengar dan membaca pada isi pesan yang ditayangkan oleh program-program pada media massa. Terpaan merupakan intensitas keadaan khalayak dimana terkena pesan -pesan yang di sebarkan oleh suatu media. Menurut Ardianto (2014:168), terpaan dapat diartikan sebagai kegiatan mendengar, melihat dan membaca pesan - pesan media ataupun mempunyai pengalaman dan perhatian terhadap pesan tersebut yang dapat terjadi pada individu atau kolompok (Respati, 2013).

Pada awalnya, banyak media massa yang memberitakan kasus covid19secara membabi buta. Media massa terutama beberapa media elektronik sering membuat bingung dan cemas masyarakat karena sering ditayangkan dengan konteks yang sama. Salah satu contohnya adalah pembaharuan informasi mengenai penambahan jumlah korban covid-19 yang hampir setiap hari diumumkan oleh divisi kementerian kesehatan RI melalui beberapa stasiun televisi di waktu yang berbeda.

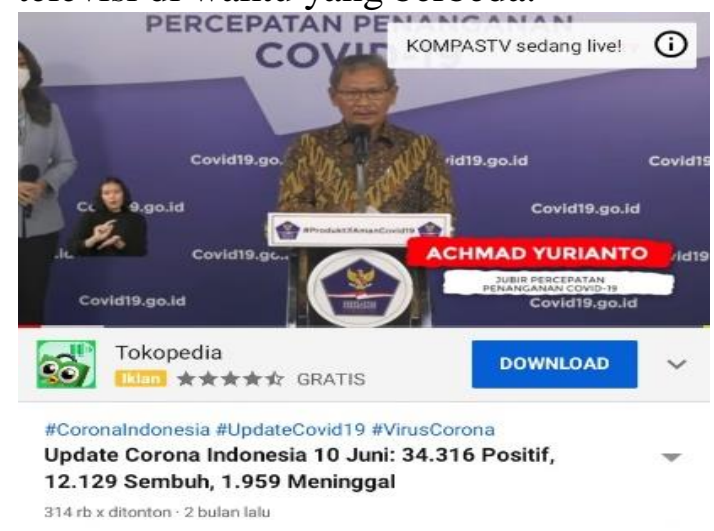

Selain itu di setiap tayangan berita selalu akan menayangkan berita mengenai perkembangan kasus covid-19 berikut adalah beberapa contoh berita yang dapat mempengaruhi sikap pedagang kaki lima.

\begin{tabular}{|l|l|l|l|}
\hline No & \multicolumn{1}{|c|}{ Stasiun TV } & \multicolumn{1}{c|}{ Judul berita } & Gambar \\
\hline 1. & INEWS & Satu Kampung di Garut Diisolasi & \\
\hline 2. & Breaking INews & Warga Desa Cigedug Isolasi Mandiri & \\
\hline 3. & $\begin{array}{l}\text { Selamat Pagi } \\
\text { Indonesia }\end{array}$ & $\begin{array}{l}\text { Isolasi Mandiri Warga Satu } \\
\text { Kampung }\end{array}$ & \\
\hline
\end{tabular}




\begin{tabular}{|c|c|c|c|}
\hline 4. & $\begin{array}{l}\text { Kabar Petang, TV } \\
\text { One }\end{array}$ & Satu Desa Diisolasi & $\frac{1}{3+1}$ \\
\hline 5. & Kabar Pagi, TvOne & $\begin{array}{l}\text { Satu Pemudik Positif Corona, } \\
\text { Seluruh Petugas Garut Jalani Rapid } \\
\text { Test }\end{array}$ & 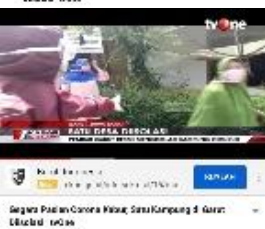 \\
\hline 6. & CNN Indonesia & $\begin{array}{l}\text { Penyebaran Kasus Covid-19 di Pasar } \\
\text { Jakarta }\end{array}$ & 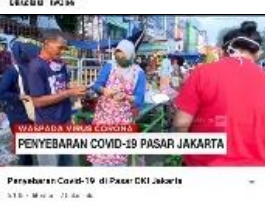 \\
\hline 7. & Kompas Pagi & $\begin{array}{l}64 \text { Pasar Menjadi Tempat Penularan } \\
\text { Virus }\end{array}$ & Ad mant If \\
\hline 8. & Redaksi & $\begin{array}{l}\text { Pasar Jadi Tempat Penyebaran Virus } \\
\text { Covid-19 }\end{array}$ & 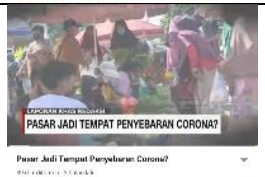 \\
\hline
\end{tabular}

Dinamika pemberitaan media massa terhadap pandemi covid-19 sebagaimana disebutkan di atas tentu tidak muncul begitu saja. Dinamika itu terjadi karena baik insan media massa maupun pemerintah, sama-sama tidak mengetahui secara pasti dalam ihwal covid-19 itu. Makanya, dalam menjalankan fungsinya masing-masing, insan media dan pemerintah sempat membuat kekeliruan. Tapi, syukurlah keduanya sudah dapat mengoreksinya.

\section{Metode}

Penelitian kualitatif ini menerapkan metode deskriptif. Sebab, hal ini mempelajari masalah-masalah dalam masyarakat, serta tata cara yang berlaku dalam masyarakat serta situasi-situasi tertentu, termasuk tentang hubungan kegiatan, sikap, pandangan, serta prosesproses yang sedang berlangsung dan pengaruh dari suatu fenomena (Hamdi, n.d.). Kajian ini menggambarkan karakteristik suatu masyarakat atau kelompok untuk mencari hubungan dua variabel kondisi situasi tertentu (Rusian, 2017).

Bagaimana langkah atau upaya yang dilakukan oleh pedagang kaki lima di kampung Cikedokan dalam mengatasi maraknya pemberitaan mengenai kasus covid-19 dan mengaplikasikan dalam kegiatan sehari harinya, sehingga pedagang kaki lima tersebut bisa melakukan pekerjaannya ditengah marak pemberitaan media yang bisa mempegaruhi masyarakat.

Paradigma

konstruktivisme membantu mengkontruksi pemikiran dan pengalaman individu mengenai pemberitaan covid-19 di media massa terutama televisi yang bisa mempengaruhi sikap masyarakat dalam melakukan kegiatan sehari harinya. Penelitian ini sejalan dengan asumsi Individual Differences theory atau teori perbedaan individu dan konsep kebijakan atau upaya yang relevan dalam menjawab fenomena (Fitryarini, 2013) 
Kecenderungan yang terjadi saat ini adalah, banyak para pedagang kaki lima yang sering menonton tayangan berita dalam televisi di masa pandemi ini. Teori perbedaan individu yang diketengahkan oleh Melvin D. Fleur digunakan dalam memahami bagaimana pedagang kaki lima tersebut, menggunakan media sebagai alat untuk memenuhi kebutuhan akan informasi masa pandemi. Karena itulah pengguna media atau khalayak, memainkan peran aktif untuk memilih dan menggunakan media (McQuail, 1987).

$$
\text { Selain itu, masyarakat }
$$
mempersepsikan berita melalui beberapa proses, mulai dari penerimaan informasi, menafsirkan isi pesan, melihat kejadian menariknya, serta pesan yang terkandung dalam berita tersebut. Banyaknya pemberitaan di media massa selama masa pandemi ini menjadi asumsi awal tidak sedikit khalayak banyak yang diterpa oleh berita, sehingga secara tidak langsung mereka akan membutuhkan berita sebagai acuan untuk mendapat informasi. Dan dalam penyampaian informasinya, walaupun pesan yang disampaikan sama, naun tanggapan serta persepsi yang terjadi akan berbeda, tergantung pada individu tersebut.

Subjek yang digunakan adalah masyarakat dengan pekerjaan pedagang kaki lima yang berjualan keliling dan pedangan kaki lima yang berjualan di pasar sebagai subjek penelitian. Serta penjabaran mengenai strategi atau cara yang dilakukan untuk mengatasi pemberitaan covid-19 dalam televisi yang menjadi objek kajiannya.

Teknik pengambilan data dilakukan dengan cara pengamatan mengenai profesi dan cara yang pedagang kaki lima lakukan selama masa pandemi Covid-19 lalu dilakukan wawancara secara individual dengan membagikan beberapa pertanyaan secara tertulis, sebagai tinjauan lebih dalam mengenai pendapat dari masing masing pedagang kaki lima yang memang terdampak oleh terpaan pemberitaan televisi, hal yang telah dilakukan oleh peneliti lalu di dokumentasikan sebagai hasil dan bukti telah melakukan wawancara dan penggalian informasi serta memperkuat data penelitian. Setelah data diperoleh, maka dilakukan analisis data.

Teknik analisis data yang dilakukan oleh peneliti diantaranya yaitu, reduksi data (data reduction), setelah pengumpulan data, lalu selektif dipilih jawaban yang sesuai dengan masalah yang sedang diteliti oleh peneliti atau bisa disebut reduksi data. Penyajian data (data display), penyajian data dilakukan dengan cara mengembangkan data dan informasi tesebut dalam bentuk uraian penjelasan. Data yang diambil selama kegiatan diambil dari data yang disederhanakan dalam reduksi data kedalam bentuk kata-kata atau narasi sesuai fakta yang ada di lapangan untuk dijadikan sebagai simpulan peneliti dengan menyusun kalimat secara logis dan sitematis sehingga mudah untuk dibaca dan dipahami. Penarikan kesimpulan (conclusion drawing/ verification), penarikan kesimpulan dari hasil pengembangan dan penyusunan data yang telah diperoleh, sehingga bisa mendapatkan hasil dari penelitian yang dilakukan (Manzilati, n.d.) Dalam mengecek keabsahan data, dapat dilakukan triangulasi.

Triangulasi dalam pengujian kredibilitas ini diartikan sebagai pengecekan data dari berbagai sumber 
dengan berbagai cara, dan berbagai waktu. Dengan demikian terdapat tiga macam, yaitu triangulasi sumber, teknik, dan waktu (Anggito \& Setiawan, 2001). Trianggulasi data diperoleh dari informan utama yaitu pedagang kaki lima yang secara langsung merupakan khalayak yang terkena terpaan berita Covid-19 adapun pedagang kaki lima yang menjadi key informan adalah pedagang kaki lima yang berjualan di pasar serta pedagang keliling. Triangulasi teknik yang dilakukan oleh peneliti, pertama dilakukan wawancara singkat, lalu dihari berikutnya dilakukan observasi, dan pembagian kuesioner. Sehingga pemahaman peneliti meningkat.

\section{Hasil dan pembahasan}

Penggunaan Televisi dalam Memperoleh Berita tentang covid-19

Jumlah sampel yang digunakan pada penelitian ini berjumlah 17 orang yang sesuai dengan kriteria-kriteria penelitian di kampung Cikedokan Desa Sukasenang Kecamatan Bayongbong, Garut. Jumlah pertanyaan yang digunakan pada wawancara penelitian ini berjumlah 10 pertanyaan. Pada penelelitian ini masalah yang dibahas adalah upaya pedagang kaki lima dalam mengatasi terpaan berita covid-19 dalam televisi. Berdasarkan hasil penelitian yang dilakukan pada 17 pedagang kaki lima yang ada di kampung Cikedokan, bahwa mereka lebih sering memperoleh informasi mengenai berita perkembangan covid-19 melalui televisi daripada media sosial. Mereka menganggap bahwa televisi bisa memberikan siaran yang membuat mereka lebih mempercayai apa yang disampaikan oleh media televisi. Dalam sehari mereka menghabiskan waktu untuk menonton berita mengenai covid19 sebanyak 3 kali, pada pagi hari, sore dan malam hari, setelah selesai bekerja, dan berita yang sering ditonton adalah berita yang ada di stasiun Metro TV dan TV One.

Para pedagang kaki lima memilih berita yang ada di Metro TV dan TV One karena stasiun televisi tersebut sering menayangkan berita mengenai perkembangan kasus covid-19secara mendalam, seperti mendatangkan narasumber yang ahli di bidang ini, untuk menyampaikan baik mengenai informasi kenaikan jumlah korban, status pandemi di setiap daerah, maupun pengetahuan mengenai cara yang haus dilakukan agar bisa mencegah penyebaran virus dengan rutin dan terkadang secara live, sehingga tidak dipungkiri informasi yang diberikan tidak bersifat hoaks atau palsu, dibandingkan dengan mengakses berita melalui media sosial yang belum tentu kebenarannya. Namun, 3 dari 17 orang pedagang kaki lima yang diwawancarai oleh peneliti, mereka mencari informasi mengenai covid-19 selain dari televisi mereka mengaksesnya melalui media sosial, karena media sosial lebih cepat menyebarkan informasi, sehingga pada saat mereka bekerja bisa langsung mengetahui informasi mengenai berita covid-19 dengan menyelaraskan kebenarannya melalui saluran berita yang ditayangkan dalam televisi. Saat pandemi covid-19 seperti ini, pemberitaan di media massa terutama dalam televisi memiliki nilai yang sangat penting bagi pedagang kaki lima. Karena dengan adanya pemberitaan mengenai 
berita tersebut mereka menjadi lebih tahu, lebih paham, dan lebih mengenal apa itu Covid-19 bagaimana cara menghindarinya, dan penyebab lonjakan covid-19 di setiap daerah di Indonesia. Untuk pedagang kaki lima, informasi mengenai covid-19 memang sangatlah penting, karena mereka harus mengetahui perkembangan kasusnya hari demi hari. Namun, semakin hari semakin banyak informasi yang justru membuat para pedagang kaki lima cemas dalam melakukan aktivitas sehari-harinya. Di televisi sendiri kenaikan jumlah pemberitaan di televisi meningkat dengan adanya perkembangan kasus setiap harinya. Berikut merupakan hasil wawancara yang telah dilakukan oleh peneliti.

\begin{tabular}{|c|c|c|}
\hline No & Pertanyaan & Uraian \\
\hline 1 & $\begin{array}{l}\text { Apakah anda lebih sering } \\
\text { menggunakan tayangan televisi atau } \\
\text { menggunakan media sosial untuk } \\
\text { mencari perkembangan kasusnya? }\end{array}$ & $\begin{array}{l}75 \% \text { pedagang kaki lima menonton } \\
\text { tayangan berita dari televisi. }\end{array}$ \\
\hline 2 & $\begin{array}{l}\text { Bagaimana pendapat anda mengenai } \\
\text { banyaknya pemberitaan mengenai } \\
\text { covid-19dalam televisi? }\end{array}$ & $\begin{array}{l}80 \% \text { pedagang kaki lima menjawab } \\
\text { mengkhawatirkan, sisanya menjawab biasa } \\
\text { saja. }\end{array}$ \\
\hline 3 & $\begin{array}{l}\text { Bagaimana perubahan perilaku/ } \\
\text { dampak yang anda rasakan setelah } \\
\text { menonton berita covid-19di televisi? }\end{array}$ & $\begin{array}{l}80 \% \text { pedagang kaki lima menjawab } \\
\text { menjadi cemas dan merasa takut, } \\
\text { sedangkan sisanya menjawab tidak terkena } \\
\text { dampak apapun. }\end{array}$ \\
\hline 4 & $\begin{array}{l}\text { Dengan maraknya pemberitaan } \\
\text { Covid-19bagaimana cara anda untuk } \\
\text { memilih berita yang anda anggap } \\
\text { penting dan anda butuhkan? }\end{array}$ & $\begin{array}{l}\text { Berita live dan ada narasumber yang ahli } \\
\text { di bidangnya. }\end{array}$ \\
\hline 5 & $\begin{array}{l}\text { Apakah dengan menonton setiap } \\
\text { berita di televisi, anda akan mudah } \\
\text { percaya akan kebenaran berita } \\
\text { tersebut? }\end{array}$ & $\begin{array}{l}\text { Tidak, berita memang sudah pasti } \\
\text { kebenarannya, tetapi kita tidak bisa } \\
\text { percaya begitu saja. }\end{array}$ \\
\hline 6 & $\begin{array}{l}\text { Apakah berita dalam televisi } \\
\text { mempengaruhi anda dalam bekerja } \\
\text { sehari hari ? Dan bagaimana contoh } \\
\text { pengaruhnya }\end{array}$ & $\begin{array}{l}70 \% \text { pedagang kaki lima menjawab } \\
\text { terpengaruh, sisanya tidak terpengaruh } \\
\text { apapun. Contohnya, seperti menjadi mudah } \\
\text { cemas dan berprasangka buruk pada orang } \\
\text { yang bergejala seperti gejala covid-19 }\end{array}$ \\
\hline 7 & $\begin{array}{l}\text { Bagaimana cara anda untuk } \\
\text { mengatasi dampak dari setiap berita } \\
\text { covid-19yang ditayangkan dalam } \\
\text { televisi? }\end{array}$ & $\begin{array}{l}\text { 1. Mengurangi tontonan mengenai berita } \\
\text { penyebaran covid-19 } \\
\text { 2. Memilih berita yang baik untuk } \\
\text { dikonsumsi } \\
\text { 3. Berpikiran Positif } \\
\text { 4. Bertanya pada yang lebih tahu. }\end{array}$ \\
\hline 8 & $\begin{array}{l}\text { Jika pemberitaan televisi } \\
\text { mempengaruhi pekerjaan anda, } \\
\text { apakah anda masih akan terus } \\
\text { meninjau perkembangan mengenai }\end{array}$ & $\begin{array}{l}80 \% \text { pedagang kaki lima menjawab, iya, } \\
\text { karena mereka masih membutuhkan } \\
\text { informasi mengenai lingkungan di } \\
\text { sekitarnya demi kesehatan diri. }\end{array}$ \\
\hline
\end{tabular}




\begin{tabular}{|l|l|l|}
\hline & virus covid-19di televisi ? & \\
\hline 9 & $\begin{array}{l}\text { Apa yang anda rasakan selama anda } \\
\text { menonton berita covid-19di televisi } \\
\text { dan harus tetap bekerja dalam } \\
\text { kehidupan sehari hari? }\end{array}$ & $\begin{array}{l}80 \% \text { pedagang kaki lima menjawab lebih } \\
\text { waspada dan mudah cemas, sisanya } \\
\text { menjawab biasa saja. }\end{array}$ \\
\hline 10 & $\begin{array}{l}\text { Bagaimana upaya yang anda lakukan } \\
\text { untuk mengatasi dampak dari anda } \\
\text { menonton berita covid-19dalam } \\
\text { televisi dan tetap melakukan } \\
\text { pekerjaan anda? }\end{array}$ & $\begin{array}{l}\text { 1.Melaksanakan anjuran pemerintah } \\
\text { 2.Mengurangi tontonan berita covid-19 } \\
\text { 3.Berperilaku selektif memilih media } \\
\text { 4.Bertanya pada orang yang ahli dibidang } \\
\text { penanganan covid-19 }\end{array}$ \\
\hline
\end{tabular}

Berdasarkan wawancara yang telah dilakukan pada pedagang kaki lima di kampung Cikedokan, masyarakat hanya menganggap penting berita yang mereka butuhkan seperti perkembangan kasus, kenaikan jumlah korban, dan hal hal yang boleh dan tidak boleh dilakukan oleh masyarakat untuk memutuskan rantai penyebaran virus covid-19 pedagang kaki lima di kampung ini sudah bisa membedakan mana informasi yang layak untuk dikonsumsi dan berita yang yang dapat mempengaruhi mereka dalam melakukan pekerjaannya.

Sebagian masyarakat menganggap penting berita yang ada dalam televisi, namun bagi sebagian besar masyarakat hanya menganggap berita sebagai acuan saja, dan hanya menganggap penting berita covid-19 mengenai bagaimana cara yang harus dilakukan untuk memutuskan rantai penyebaran virus ini.

Upaya mengatasi terpaan berita covid-19 di televisi

Dari 17 orang responden kesemuanya menganggap bahwa pemberitaan kasus covid-19untuk disiarkan melalui media eletronik, tentu saja dalam pemberitaan di media elektronik harus disesuaikan dengan batas-batas norma di masyarakat dan tidak harus ditulis secara detail dan kejadiannya. Media massa memiliki potensi mempengaruhi bahkan bisa membentuk opini publik secara masif, tetapi terpaannya dalam konteks pemberitaan mengenai bahaya penyebaran virus covid-19 bisa menjadi spekulatif. Jika pemirsa, dalam hal ini responden, tidak menyimak secara intensif atau dengan sengaja mencari informasi lewat media, hanya sesekali dengan secara kebetulan menyimaknya, maka terpaan media pun menjadi spekulatif saja, yang terbukti dalam penelitian ini menyebabkan responden hanya mengetahui dan sedikit memahami.

Terpaan media, suatu kondisi dimana khalayak diterpa oleh suatu isi pesan dalam media atau bagaimana media menerpa khalayaknya. Meninjau dari hal tersebut, berdasarkan penelitian yang telah dilakukan, bahwa pedagang kaki lima merupakan khalayak yang diterpa media, seperti halnya menurut 
Elvinaro (2004) untuk mengukur terpaan media dapat dilihat dari 3 faktor

1. Frekuensi, dengan adanya pandemi ini, para pedagang kaki lima menjadi lebih sering melihat berita yang ada di televisi walaupun harus tetap melaksanakan pekerjaannya, sehingga semakin hari sering melihat berita, maka hal tersebut menimbulkan perhatian dari pedagang kaki lima.

2. Perhatian (atensi), dalam melihat tayangan media, para pedagang kaki lima menaruh perhatian dan fokusnya ke dalam media tersebut, sehingga mereka menjadi tertarik dengan apa yang disampaikan oleh berita tersebut. Mereka menyimak dan memperhatikan berita tersebut, karena mereka membutuhkan informasi supaya tetap bisa melaksanakan pekerjaannya disamping peristiwa yang sedang terjadi.

3. Durasi, dalam sehari, mereka menghabiskan waktu selama 4 jam untuk menonton berita yang ada di televisi, baik di pagi hari, sore, dan bahkan malam hari, karena mereka masih membutuhkan informasi mengani covid-19.

Hasil temuan terkait dengan terpaan berita perkembangan kasus covid-19 di media massa menunjukkan sebagian besar responden mendapatkan dalam kategori sedang. Sementara, hanya sedikit mendapatkan terpaan berita dalam kategori tinggi. Hal ini menunjukkan bahwa masyarakat masih tertarik dan mengikuti pemberitaan covid-19 khususnya pemberitaan yang terkait dengan penambahan jumlah korban yang terkena virus covid-19 cara penularan, dan penanganannya. Hasil temuan terkait dengan pentingnya berita covid-19 dalam berita televisi menunjukkan, responden menilai berita tersebut membuat para responden merasa terganggu dengan adanya berita yang ditayangkan setiap saat mengenai bahayanya virus ini, dan menimbulkan efek seperti cemas, khawatir padahal mereka harus tetap beraktivitas dan bertemu dengan banyak orang di luar saat bekerja. Namun, hanya sedikit responden yang menilai bahwa mereka bersikap biasa saja dengan adanya berita tersebut, dan tidak menghiraukan apa yang disampaikan oleh berita tersebut. Hal ini berarti masyarakat menilai bahwa pemberitaan mengenai covid-19 di televisi memberikan efek masing-masing ada yang menganggap bahwa berita tersebut memberikan pengetahuan dan ada juga yang menganggap berita membawa kecemasan, sehingga perlu adanya literasi yang baik untuk menunjukkan bahwa tidak semua berita bisa dikonsumsi begitu saja. Meskipun tidak seluruhnya menilai bahwa berita di televisi dianggap meresahkan, ada juga yang menyerap informasi dari berita untuk diaplikasikan dalam kehidupannya sehari hari, seperti penggunaan protokol kesehatan dari pemerintah supaya tetap terhindar dari virus covid-19.

Tidak kalah mengkhawatirkan cara pengemasan berita yang kerap tidak mengikuti kaidah jurnalistik. Untuk menarik khalayak, stasiun televisi mencoba menggugah emosi khalayak dengan jurus-jurus eksploitasi kesedihan korban termasuk ekspos tindak penanganan bahkan penambahan jumlah korban baik secara narasi maupu visualisasi. Hal-hal tersebut justru menyesatkan khalayak dari substansi berita itu sebenarnya. 
Hasil menunjukkan bahwa masyarakat dapat melihat sebenarnya kendali pemilihan program yang akan ditonton pada akhirnya bermuara pada keputusan khalayak. Bila mayoritas khalayak sepakat program yang menurut mereka ideal untuk ditonton, otomatis pelaku industri media akan mengikuti apa yang mereka inginkan, karena khalayak adalah pasar sebenarnya. Khalayak juga diharapkan dapat menciptakan filter bagi dirinya sendiri untuk memaksimalkan porsi manfaat dan meminimalisasi dampak negatif. Idealnya selain memberikan informasi, wawasan, pengetahuan dan perkembangan budaya, televisi memiliki kecepatan dan keakuratan dalam menyajikan berita, melebihi media massa lainnya seperti surat kabar dan radio

Sementara itu, pengaruh negatif yang harus disadari khalayak di antaranya: terlalu lama menerima terpaan televisi dapat mengurangi produktivitas, menerima terpaan televisi tanpa logika kritis menjauhkan khalayak dari realita, dapat memengaruhi cara berinteraksi dengan keluarga dan masyarakat sekitar, dalam situasi pandemi ini akan menimbulkan kecemasan yang berlebihan, selalu merasa curiga pada seseorang yang sedang mengalami gejala seperti covid19 bahkan pendapatan tidak seperti biasanya, karena masyarakat tidak banyak membeli makanan yang disajikan secara langsung.

Pemberitaan media massa mengenai perkembangan covid-19 menurut pedagang kaki lima di kampung Cikedokan, berita tersebut memiliki nilai yang kurang bermanfaat bagi penonton atau audiens yang menontonnya, karena berita tersebut terlalu sering ditayangkan sehingga masyarakat menjadi bosan dan bersikap seperti tidak terjadi apa apa di lingkungan sekitarnya. Karena pemberitaan yang terus menerus, masyarakat menjadi tidak menonton berita dan malah tidak mau ambil pusing dengan peristiwa yang sedang terjadi.

Berdasarkan teori perbedaan individu atau individual differences theory, menunjukkan bahwa pada dasarnya setiap individu dalam menerima stimuli atau informasi, mereka memiliki penilaian yang berbeda-beda dalam menanggapi rangsangan tersebut karena setiap individu memiliki karakter yang berbeda satu dengan yang lain (Effendy, 2006).

Program berita pada warga kampung Cikedokan yang menjadi sampel dalam penelitian yang tidak sama pada stimuli yang sama yakni informasi serta hiburan yang diberikan oleh berita tersebut. Banyak warga yang menganggap bahwa lama kelamaan, pemberitaan media televisi mengenai covid-19 tidak begitu di perhatikan seperti awalnya muncul kasus itu. Namun, ada pula yang menganggap berita tersebut menarik untuk ditonton karena adanya pesan-pesan positif dan sebagai salah satu pengetahuan untuk mencegah terserangnya virus covid-19.

Berbagai macam pemberitaan yang di tampilkan oleh media sedikit banyaknya pasti akan menimbulkan berbagai macam dampak yang terjadi dalam masyarakat. Oleh karena itu, kita harus memikirkan bagaimana cara mengatasi hal tersebut tentang penanganan atau upaya-upaya yang dilakukan untuk dapat menekan atau mengatasi banyaknya terpaan berita yang ditayangkan dalam televisi. 
Apalagi terhadap dampak-dampak negatif yang ditimbulkan oleh pemberitaan yang ditampilkan oleh media terutama pada pemberitaan tentang penyebaran virus covid-19. Oleh karena itu, diharapkan kepada masyarakat dalam menyaksikan acara pemberitaan yang ditampilkan di layar kaca supaya tidak mudah untuk terpancing dan terpengaruh dengan pemberitaan yang ditampilkan karena pemberitaan yang di beberikan oleh media kepada masyarakat itu bersifat informatif, membutuhkan pemahaman yang cukup tinggi, karena apabila pemberitaan tersebut tidak di pahami dan di salah artikan oleh masyarakat hal tersebut dapat memunculkan berbagai perbedaan pendapat oleh masyarakat serta dapat melakukan hal-hal yang tidak sesuai dengan peraturan yang ada.

Selain itu, masyarakat juga perlu diberikan penyuluhan-penyuluhan yang berhubungan dengan sikap dan nilainilai moral yang perlu di terapkan dalam masyarakan agar dapat mengurangi gejala cemas atau kekhawatiran yang berlebihan. Sesuai dengan yang diungkapkan di atas, bahwa masyarakat dalam menyaksikan pemberitaan tentang penyebaran virus covid-19 yang di tampilkan oleh media khususnya media elektronik harus mengerti betul terhadap apa yang ditampilkan oleh media karena ketika seseorang salah akan mengartikannya maka di dalam masyarakat akan terjadi perbedaan yang dapat menimbulkan sesuatu yang dapat menghawatirkan diri sendiri dan orang lain.

Dampak negatif seperti timbulnya kecemasan, rasa khawatir saat melakukan kontak dengan yang lain, menyinggung orang lain, dan berprasangka buruk terhadap orang yang sedang memiliki gejala seperti gejala orang terkena virus covid-19 dan menimbulkan rasa malas untuk melakukan sesuatu. Selain itu, ada yang beranggapan bahwa berita di media massa tidak mempengaruhinya sama sekali, mereka menganggap biasa saja terhadap berita yang ditayangkan. Dan ada pula yang menganggap bahwa berita yang ditayangkan dalam televisi dapat memberikan pemahaman lebih mengenai virus covid-19 mengetahui cara mengatasi dan memutus rantai penyebaran, mengetahui tindak lanjut pemerintah dalam membuat protokol kesehatan selama pandemi ini.

Mengatasi maraknya terpaan berita dalam televisi, banyak upaya yang dilakukan, dan upaya yang mereka lakukan untuk mengatasi pemberitaan covid-19 dalam televisi, ada yang memilih untuk mengalihkan saluran berita pada saluran hiburan, ada yang berhenti menonton berita, dan ada juga yang menonton berita tetapi bertanya lagi kepada yang lebih tahu seperti orang yang ahli dalam bidang kesehatan dan yang lainnya, supaya tidak menimbulkan kesalahpahaman dari apa yang disampaikan oleh media dan yang harus dilakukan oleh diri masing masing selama pandemi ini. Menyamakan antara berita televisi dan media sosial, untuk mencari informasi yang benar, maka pedagang tersebut akan menyamakan antara berita di televisi dan mencari tahu lebih lanjut melalui media sosial.

Upaya lain dalam mengatasi terpaan berita covid-19 di televisi adalah dengan tidak mencari tahu secara terus menerus mengenai informasi mengenai perkembangan covid-19 karena mereka menganggap hal tersebut hanya 
menambah kepanikan dan rasa cemas dalam diri sendiri. Mengikuti arahan pemerintah yang efektif juga penting, dan lebih selektif dalam memilih mana berita yang baik untuk dikonsumsi dan mana berita yang hanya menambah kekhawatiran saja, dan menghindari pemberitaan yang menakutkan dan membuat kita down dengan tidak sering menonton berita mengenai covid-19. Selalu berpikiran positif, dan mengurangi konsumsi pemberitaan agar tidak menggangu pekerjaan, dengan melihat perkembangan kasus dari televisi, dan mengaplikasikan dalam kehidupan sehari hari. Memilih berita live sesuai dari pemerintah, dan melihat keadaan yang sesuai dengan kenyataan tanpa menghiraukan arahan pemerintah.

Selain itu, kita sebagai umat muslim harus yakin dan percaya bila sedang tertimpa penyakit, maka yakinlah bahwa Allah juga yang akan menyembuhkannya, dan kita berlindung dari wabah ini kepada Allah. Seperti dalam AlQur'an surat At-Taubah ayat 51
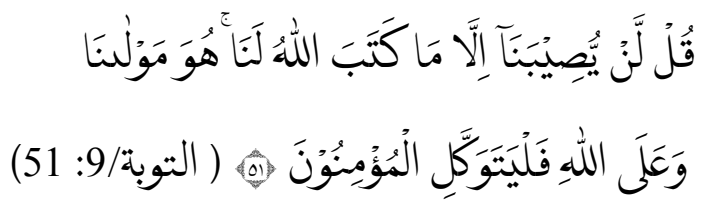

Katakanlah (Muhammad), "Tidak akan menimpa kami melainkan apa yang telah ditetapkan Allah bagi kami. Dialah pelindung kami, dan hanya kepada Allah bertawakallah orang-orang yang beriman." (At-Taubah/9:51)

Datangnya musibah harus dihadapi dengan penuh keimanan. Keimanan yang akan membuat kita selalu berpikiran positif dalam memandang suatu musibah, hal itu sejalan dengan firman Allah QS Al Taghobun: 11.

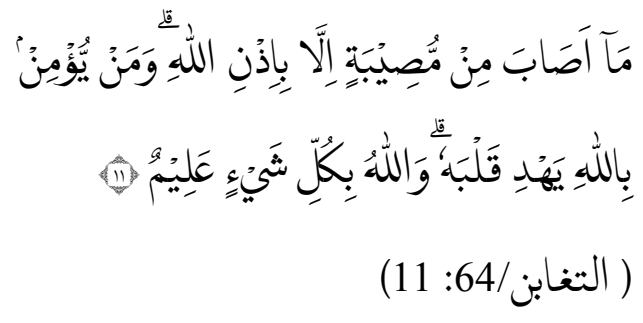

Tidak ada sesuatu musibah yang menimpa (seseorang), kecuali dengan izin Allah; dan barangsiapa beriman kepada Allah, niscaya Allah akan memberi petunjuk kepada hatinya. Dan Allah Maha Mengetahui segala sesuatu. (At-Tagabun/64:11)

\section{Kesimpulan}

Berdasarkan pembahasan diatas, maka, pedagang kaki lima termasuk kepada khalayak yang terkena dampak dari pemberitaan dari media televisi, dari sekian banyak terpaan berita, mereka menganggap berita mengenai penyebaran covid-19 tersebut penting, karena mereka bisa mengetahui efek positif dan negatif dari penyebaran virus tersebut, untuk tetap bisa melakukan aktifitas sehari hari dalam bekerja dan bertemu dengan orang banyak. Adapun upaya yang dilakukan untuk mengurangi dampak terpaan berita media massa diantaranya, dengan mengurangi konsumsi berita setiap saat, lebih selektif dalam memilih berita yang benar, berpikiran positif, dan mencari tahu kebenaran berita tersebut dengan bertanya dan menyelaraskannya pada orang yang ahli di bidang kesehatan. penting juga untuk tidak merasa panik dan cemas sebelum mengetahui kebenaran dari berita tersebut. Walaupun dampak dari adanya virus ini perekonomian semakin sulit, tetapi adanya berita ini bisa menambah pengetahuan dan wawasan mengenai 
virus tersebut, dan cara penanganannya, seperti menjaga kebersihan dan melakukan hal sesuai dengan protokol yang telah ditetapkan pemerintah.

\section{Referensi}

Abraham, R. H. (2017). Pemberitaan

Dalam Media Massa Televisi

Terkait Pemilihan Presiden 2014.

Interaksi: Jurnal Ilmu Komunikasi, 5(1), 201.

https://doi.org/https://doi.org/10.147

10/interaksi.5.2.201-208

Alamsyah, F. F., Amaliasari, D., \&

Satriani, I. (2018). Tingkat

Kepercayaan Khalayak terhadap

Pemberitaan di Media Massa di

Kota Bogor (Pengembangan Media

Literasi Pada Khalayak). Jurnal

Komunikasi Pembangunan, 16(2), 266-273.

Anggito, A., \& Setiawan, J. (2001).

Metodologi Penelitian Kualitatif.

CV Jejak (Jejak Publisher).

Effendy, O. U. (2006). Ilmu, Teori, dan

Filsafat Komunikasi. PT: Citra

Aditya Bakti.

Gussman, S. Y., \& Triwulandari. (2019).

Pengaruh Terpaan Berita BPJS di

Media Massa Terhadap

Pembentukan Sikap Masyarakat di

Kota Pekanbaru. Communiverse,
4(2), 42-50. Retrieved from

http://jurnal.univrab.ac.id/index.php

/cmv/article/view/859

Hamdi, A. S. (n.d.). Metode Penelitian

Kuantitatif Aplikasi dalam

Pendidikan.

Lokadata.id. (2020a).

https://lokadata.id/artikel/lonjakankasus-covid-19-tertinggi-sepanjangmaret-2020.

Lokadata.id. (2020b).

https://lokadata.id/artikel/penontondan-pengiklan-di-tv-mulai-beralih.

Manzilati, A. (n.d.). Metodologi

Penelitian Kualitatif: Paradigma, Metode, dan Aplikasi. Universitas

Brawijaya Press.

Nadie, L. (2018). Media Massa dan Pasar ModaL: Strategi Komunikasi bagi Perusahaan Go Public. Media Center.

Nielsen.com. (2020).

https://www.nielsen.com/id/id/pressreleases/2020/covid-19-dandampaknya-pada-tren-konsumsimedia.

Nuruddin. (2007). Pengantar KomunikasiMassa. Jakarta: RajaGrafindo. 
Respati, W. (2013). Media Literasi:

Upaya Bijak Menyikapi Terpaan

Tayangan Televisi. Humaniora, 4(1), 619.

https://doi.org/https://doi.org/10.215

12/humaniora.v4i1.3471

Rusian, R. (2017). Metode penelitian

public relations dan komunikasi

(7th ed). PT RajaGrafindo Persada.

Voaindonesia. (2020).

https://www.voaindonesia.com/a/vir us-corona-di-media-edukatif-ataubikin-panik-/5321258.html.

Yadewani, D., Syafrani, \& Ikhsan. (2020). Memilih Menjadi Pedagang Kaki

Lima: Sebuah Kajian Persepsi

Pedagang Kaki Lima. Pustaka Galeri Mandiri. 
This page intentionally left blank. 